\title{
China and India: Income inequality and poverty north and south of the Himalayas
}

\author{
Vani K. Borooah ${ }^{\mathrm{a}, *}$, Björn Gustafsson ${ }^{\mathrm{b}, \mathrm{d}}$, Li Shi ${ }^{\mathrm{c}, \mathrm{d}}$ \\ ${ }^{a}$ School of Economics and Politics, University of Ulster, Newtownabbey, Northern Ireland BT37 OQB, UK \\ ${ }^{\mathrm{b}}$ Department of Social Work, University of Göteborg, P.O. Box 720, SE 40530 Göteborg, Sweden \\ ${ }^{\mathrm{c}}$ School of Economics and Business, Beijing Normal University, 19 Xin Jie KouWai Da Jie, Beijing, PR China \\ ${ }^{\mathrm{d}}$ Institute for the Study of Labor (IZA), Bonn, Germany
}

Received 8 September 2005; received in revised form 1 August 2006; accepted 14 August 2006

\begin{abstract}
China and India are the most populous countries of the World and also the two largest contributors to World poverty as assessed by the World Bank. This paper, focusing on the rural circumstances is the first study using microdata to compare income inequality and poverty in the two countries. We find that at the mid-1990s income inequality in rural China and rural India were relatively similar.

Our results show that differences in mean income across regions are much larger in China than in India and accounts for a much larger proportion of income inequality in rural China. The proportion of the population falling under a poverty line set to US\$ 1 per person and day in western China is similar to the corresponding proportion in several Indian regions but much higher than in the prosperous eastern part of China. Economic status in India is more influenced by education of household head than in China where fewer are illiterate. Common to both countries is that minority status as well as land status affect income and poverty.
\end{abstract}

(C) 2006 Elsevier Inc. All rights reserved.

JEL classification : D31; I32; O15; P52

Keywords: China; India; Income; Inequality; Poverty

\section{Introduction}

China and India are the most populous countries in the World. They are also the largest contributors to World poverty as assessed by the World Bank (see, for example, World Bank, 2000).

\footnotetext{
* Corresponding author. Tel.: +44 2890366934; fax: +44 2890961356.

E-mail addresses: VK.Borooah@ulster.ac.uk (V.K. Borooah), Bjorn.Gustafsson@socwork.gu.se (B. Gustafsson), lishi89@263.net (S. Li).
} 
However, although they are on the same continent, China and India differ in their historical experience and their institutional arrangements and this leads to substantial differences in how households and their members fare in the two countries. The overall purpose of this paper is to compare income inequality and poverty among rural residents in China and India in the mid-1990s.

We ask whether, and how, income inequality and poverty differ between the rural areas in the two countries. Since average income in China was higher than in India in the middle of the 1990s, we expect to be able to confirm that poverty, defined as living in a household whose income was less than the income associated with a 'poverty line', was more extensive in rural India than in rural China.

The main purpose of the paper is to compare how the region of residence in a country, as well as household characteristics - such as the educational level of the household head, access to land and minority-majority status - affected the income and poverty status of persons in the two countries. China's transformation towards a market economy has had a very clear spatial character with the eastern part leading prosperity in China and the western part lagging behind; this has led to substantial regional disparities. In contrast, restrictions on geographical mobility have been less stringent in India and, in the mid-1990s its labour market was more developed than of China.

While we expect rural India to be more egalitarian than China in terms of regional disparities, we might expect China to be more egalitarian than India when the populations of the two countries are disaggregated according to household characteristics. First, the income premium to education has been lower in rural China than in rural India. This is for several reasons: China's education policy during the egalitarian époque resulted in a relatively small number of workers without any education while, in India, the number of workers without any education has been considerably larger; the demand for highly educated labour in China is very much confined to its urban areas.

Second, the ethnic minority-majority dimension can be expected to play a larger role in India than in China. Ethnic minorities in China make up about $9 \%$ of its population. Although persons from minority groups are economically disadvantaged in both countries, in China this is very much related to they being over-represented in the western part of the country which has benefited less from economic growth than the eastern part.

If one defines the minority group in India as consisting of persons who are 'marginalised' relative to others, then Muslims and the 'untouchable castes' (Scheduled Castes and Scheduled Tribes) fall into this group and nearly $30 \%$ of India's population fall into the minority category (Borooah, 2005).

Third, for historical reasons many rural households in India are landless while a few are wealthy landowners. In contrast, almost all households in rural China have user rights to lands and, as a social category, landowners disappeared half a century ago. However, while, compared to India, land is equally distributed in China, access to land, and particularly to irrigated land, varies from province to province, county to county, and even from household to household.

Many cross-country comparisons of income distribution and poverty using microdata have been reported in the literature. However, such studies typically refer to industrialised countries. There are many studies comparing China and India from various aspects. However, to our knowledge before this study no one has compared income distribution and poverty in China and India using microdata.

The paper is organised as follows: the next section (Section 2) provides an institutional background to the analysis reported in the subsequent sections. The datasets used for the analysis are described in Section 3. Results on income inequality are reported and discussed in Section 4 while Section 5 presents results on poverty. Section 6 summarises the findings and concludes the paper. 


\section{The broader frame of the comparison}

China and India can be compared from various perspectives. ${ }^{1}$ This study focuses on the rural populations of the two countries. Such people constitute a majority of the populations of both China and India. However, in both China and India, the rural and urban economies are intimately linked. Despite its rhetoric, China's development strategy has focused on its urban areas. During the earlier years of the People's Republic, industrialisation took place in the country's urban areas where workers, very few of whom paid income tax, had life long relations with their work units, were provided subsidised food and housing, and received retirement pensions. Rural inhabitants, on the other hand, were disfavoured in all these respects with the consequence that the ruralurban income gap in China has been rather large (see, for example, Knight \& Song, 1999). Strong restrictions on geographical mobility, the hukou system, meant that rural to urban migration has been difficult.

In India the situation has been rather different. As Drèze and Sen (1995) have pointed out, China's real achievements lie in the field of health and education with dramatic reductions in infant and child mortality and increases in longevity and the achievement of near-universal literacy. By contrast, India's record in field of social progress - with the exception of particular states like Kerala - has been relatively disappointing. After the reforms of 1979, Chinese economic growth has been very rapid and this has allowed the use of economic resources to reduce poverty and improve living standards. By contrast, India, with its lower rate of growth has fared less well in this field: while India, too, has reduced poverty the results have been less marked than in China.

There are several implications, for the broader issue of comparing China as a whole with India as a whole, which follow from our comparison between China and India in the context of their rural populations. First, we are not observing the urban parts where the difference across countries in average living standards is highest. Second, China is somewhat more urbanised than India. ${ }^{2}$ From these observations, it follows that a comparison between China and India, in their entirety, would most likely show a larger average income gap between them than when the comparison is restricted to their rural populations only. For example, according to World Bank (2000) in 1999 average GDP per-capita was 73\% higher in China than in India when comparisons are based on dollars while the difference was 53\% when based on PPP. This can be compared to the difference of $33 \%$ for rural areas in 1995 as reported in this paper (Table 1).

Turing to income inequality, available evidence point in the direction of income inequality in urban China being smaller than in rural China. ${ }^{3}$ However, as the income gap between rural and urban parts is most likely larger in China than in India, we do not know if a comparison of income inequality in China with that in India, in their entirety, would lead to different conclusions than those obtained from confining the comparison to just their rural areas. ${ }^{4}$

\footnotetext{
${ }^{1}$ A recent example having an emphasis on the macroeconomy and the external sector see Srinivasan (2004).

${ }^{2}$ According to World Bank (2000), 32\% of the population in China 1999 lived in urban areas while the corresponding proportion in India was $28 \%$.

3 See, for example, Gustafsson and Li (2001) or Khan and Riskin (2001).

${ }^{4}$ World Bank (2000) reports a somewhat lower Gini coefficient for disposable income in India as whole (37.8\% in 1997) than for China as a whole (40.3\% in 1998). However, the top decile in India received a larger proportion of total income than the top decile in China. Thus, those two criterions provide different ranking of the two countries as a whole with respect to income inequality.
} 
Table 1

Per-capita household income in rural China 1995 and in rural India 1993/1994, by region

\begin{tabular}{|c|c|c|c|c|c|c|}
\hline & Central & South & West & East & North & National \\
\hline \multicolumn{7}{|l|}{ Rural India } \\
\hline Mean income (PPP US\$) & 606 & 769 & 850 & 536 & 774 & 680 \\
\hline Population share & 40 & 20 & 13 & 14 & 12 & 100 \\
\hline Income share & 36 & 23 & 16 & 11 & 13 & 100 \\
\hline Relative mean & 0.89 & 1.13 & 1.25 & 0.79 & 1.14 & 1.0 \\
\hline $\mathrm{GE}(0)$ & 0.31 & 0.40 & 0.41 & 0.29 & 0.30 & 0.35 \\
\hline GE(1) & 0.33 & 0.46 & 0.47 & 0.28 & 0.30 & 0.39 \\
\hline Gini & 0.42 & 0.48 & 0.49 & 0.41 & 0.41 & 0.45 \\
\hline \multicolumn{7}{|l|}{ Rural China } \\
\hline Mean income (PPP US\$) & 706 & & 555 & 1352 & & 904 \\
\hline Population share & 38 & & 26 & 36 & & 100 \\
\hline Income share & 30 & & 17 & 53 & & 100 \\
\hline Relative mean & 0.79 & & 0.64 & 1.47 & & 1.0 \\
\hline $\mathrm{GE}(0)$ & 0.20 & & 0.23 & 0.34 & & 0.32 \\
\hline $\mathrm{GE}(1)$ & 0.21 & & 0.30 & 0.37 & & 0.37 \\
\hline Gini & 0.33 & & 0.37 & 0.44 & & 0.42 \\
\hline
\end{tabular}

US\$ $1=$ Rs. 6.64 on PPP basis for India, and US\$ $1=2.56$ Yuan for China.

In both China and India, most of the poor are to be found in the rural areas. In addition, in both countries, many people have moved into cities in an effort to escape rural poverty. However, our comparison does not cover this aspect of poverty. Many visitors to both countries comment that, unlike in China, urban poverty is more visible in India where slums are commonplace. China's urban poor of the mid-1990s - particularly in middle-sized and small cities - were not only disadvantaged rural migrants, but also an increasing number of laid off workers. It might well be the case that poverty rates in urban India are higher than in urban China. However, the urban population is slightly larger in China so it is less clear if there are more urban poor in India than in China.

Our comparison of China and India refers to a point in time: the mid-1990s. Would the results have been different if similar data for a different year had been available? Since economic growth has been more rapid in China than in India, the gap in average income between them should have been smaller for earlier years but larger for later years. Available studies indicate only small changes in income inequality in India during the last decade while there seems to be a consensus that income inequality in China has increased during its transformation towards a market economy (at least until the mid-1990s). Consequently, the comparisons of income inequality between the two countries are quite likely to be affected by the timing of the comparison.

\section{Data and assumptions}

Our data for rural China comes from a survey conducted by the Institute of Economics, Chinese Academy of Social Sciences, with the assistance of the National Bureau of Statistics in Beijing. The survey refers to 1995 and was conducted during the period of January-March 1996. The sample was derived from larger samples of the National Bureau of Statistics. The questionnaires were designed by the members of the research team. Both questionnaires contain fairly comprehensive questions about household income and its components. Based on the answers, the subsistence income of rural residents can be derived. The questionnaires asked for 
the present value of private houses, which enables imputed rents to be derived by adopting a discount rate. ${ }^{5}$ Total household income is the sum of money income (wages, salaries, net revenue from farming and business), subsistence income, income in-kind from owner-occupied housing as well as transfer income net of income taxes and fees.

The Chinese data cover rural households from 19 provinces. These were then grouped by us into three regions: the eastern region comprised Beijing, Liaoning, Jiangsu, Zhejiang, Shandong and Guangdong; the central region comprised Hebei, Shanxi, Jilin, Anhui, Jiangxi, Henan, Hubei and Hunan; and the western region comprised Sichuan, Guizhou, Yunnan, Shaanxi and Gansu. Those three regions are often used in political analysis and discussion and recent policy has been to prioritise development in the western region. There are 8000 households and 34,700 individuals in the sample.

The results for India are based on data from a survey of 33,000 rural households - encompassing 195,000 individuals - which were spread over 1765 villages, in 195 districts, in 16 states of India. This survey - commissioned by the Indian Planning Commission and funded by a consortium of United Nations agencies - was carried out by the National Council of Applied Economic Research (NCAER) over January-June 1994 and most of the data from the survey pertains to the year prior to the survey, that is to 1993-1994. Details of the survey are to be found in Shariff (1999).

The NCAER Survey contained information for each of 16 states in India, the states - with their own legislatures and ministerial executives - being the basic political unit in India. These states cover nearly $90 \%$ of the Indian population and the estimates relating to 'India' pertain to analysis according to these 16 states. In this study, the states were aggregated to form five regions: the central region consisting of Bihar, Madhya Pradesh, Rajasthan and Uttar Pradesh; the south consisting of Andhra Pradesh, Karnataka, Kerala and Tamil Nadu; the west consisting of Maharashtra and Gujarat; the east consisting of Assam, Bengal and Orissa; and the north consisting of Haryana, Himachal Pradesh and Punjab.

National Accounts are harmonised across countries when it comes to definitions and measurement of GDP, GNI and its components. This is not the case for household income surveys, although there now exist recommendation aiming to increase comparability across countries (see Smeeding \& Weinberg, 2001). The Luxembourg Income Study (LIS, http:// www.lisproject.org/) is an ambitious attempt to increase comparability in definitions in household income surveys conducted in rich countries. In our research, we have followed the same approach that is we aimed to make the definitions applied in the statistical analysis for the two datasets as similar as possible. The basis for this work were documents and questionnaires of the two surveys, and knowledge accumulated by two of the authors when being involved in the process of collecting the Chinese data. However, comparability across surveys is far from perfect. For example, it can be noted that the Indian sample comprises of many more households, meaning that estimates are potentially more precise. Often household surveys underestimate true income inequality due to non-reporting of income particularly prevalent among households with the lowest and the highest income. We do not know if this problem differs systematically between the countries compared, but in many cases we report differences across the two countries that are simply too large to be thought of as caused by measurement problems only.

\footnotetext{
${ }^{5}$ For more information on the survey, see Khan and Riskin (1998). The questionnaires are reproduced in $\mathrm{Zhao,} \mathrm{Li,} \mathrm{and}$ Riskin (1999). Several authors (Gustafsson \& Li, 2004; Gustafsson \& Wei, 2000, 2002; Khan \& Riskin, 2001; Riskin \& $\mathrm{Li}, 2001$ ) have used the surveys to study rural poverty in China and its change, none have used it for a cross-country comparison of poverty.
} 
In this paper, we divide total household income by the number of persons in the household. Then we assign this value of per-capita income to each household member and perform the analysis using individuals as unit of analysis. In order to make comparisons of income levels across the samples we use estimates of PPP. We work with two alternative poverty lines, an 'absolute' poverty line and a poverty line which is relative to the rural part of the country investigated (relative poverty). The former is the World poverty line of the World Bank which is defined as US\$ 1 Purchasing Power Parity per person per day (1985 prices, see World Bank, 2000) brought forward by CPI and which should thus represent the same purchasing power in both countries. ${ }^{6}$ This approach is most common when assessing poverty in developing countries. However, when comparing developed countries the approach of defining the poverty line as a proportion of median (or mean) income as it appears in the country studied is the most applied method. This means that 'poverty' is an aspect of the distribution of income and, as an alternative, we also apply this approach.

\section{Inequality in rural India and in rural China}

Table 1 shows levels of mean household per-capita income (in PPP dollars) for (rural) India and (rural) China and for their respective regions. It is clear from the tables that mean household per-capita income in rural China, at US\$ 904, was nearly one-third higher than the corresponding Indian level of US\$ 680. The prosperous eastern region of China, with $36 \%$ of the households in the sample, received $53 \%$ of total rural income and enjoyed a mean rural household per-capita income that was $47 \%$ above the Chinese average; conversely, the poor western region of China, with $26 \%$ of the households in the sample, received $17 \%$ of total rural income and enjoyed a mean household per-capita income that was only $64 \%$ of the Chinese average. By contrast, the prosperous western, northern and southern regions in India, with $45 \%$ of the households in the sample, received $62 \%$ of total rural income and enjoyed a mean household per-capita income that was $16 \%$ above the Indian average.

Comparing the richest regions of India and of China, mean household per-capita income in the eastern region of China, at US\$ 1352, was 60\% higher than the US\$ 850 in western India; however, comparing the poorest regions of India and of China, mean household per-capita income in the western region of China, at US\$ 555, was almost identical to the US\$ 536 in eastern India. In this sense the western region of China is more similar to India than to the prosperous eastern part of China.

Overall income inequality in rural China (Gini coefficient $=0.42$ ) was slightly lower than in rural India (Gini coefficient $=0.45$ ) and inequality in the most prosperous regions of China (the eastern region) and in India (the western region) - with Gini coefficients of, respectively, 0.44 and 0.49 - was higher than in the other rural regions of the respective countries.

Table 2 shows income and inequality levels by different population subgroups. Starting with education, we report that only $13 \%$ of Indian, and $9 \%$ of Chinese, rural persons lived in a household with 'well-educated' head (professional school and college graduates in China, 10 years or above of schooling in India) and, the per-capita income of such persons was not very different between India (US\$ 1068) than in China (US\$ 1095). At the same time, only $11 \%$ of Chinese rural persons, but half of Indian rural persons, lived in a household with an illiterate

\footnotetext{
${ }^{6}$ The poverty line for China at US\$ 1 per day was 934 Yuan and for India Rs. 2422 per year.
} 
Table 2

Per-capita household income in rural China 1995 and in rural India 1993/1994 by minority/majority status; educational qualifications of $\mathrm{HoH}$; land ownership

\begin{tabular}{|c|c|c|c|c|c|c|c|}
\hline & Majority & Minority & $\begin{array}{l}\text { Education } \\
\text { low: } \\
\text { illiterate }\end{array}$ & $\begin{array}{l}\text { Education } \\
\text { medium: } \\
\text { below Matric }\end{array}$ & $\begin{array}{l}\text { Education } \\
\text { high: Matric } \\
\text { and above }\end{array}$ & Land & No land \\
\hline \multicolumn{8}{|l|}{ Rural India } \\
\hline $\begin{array}{l}\text { Mean income } \\
\text { (US\$ PPP) }\end{array}$ & 802 & 539 & 561 & 710 & 1068 & 768 & 477 \\
\hline Population share & 54 & 46 & 50 & 37 & 13 & 70 & 30 \\
\hline Income share & 63 & 37 & 41 & 39 & 20 & 79 & 21 \\
\hline Relative mean & 1.17 & 0.79 & 0.82 & 1.04 & 1.57 & 1.13 & 0.70 \\
\hline $\mathrm{GE}(0)$ & 0.37 & 0.28 & 0.31 & 0.34 & 0.42 & 0.35 & 0.27 \\
\hline GE(1) & 0.40 & 0.31 & 0.34 & 0.38 & 0.44 & 0.39 & 0.28 \\
\hline \multirow[t]{2}{*}{ Gini } & 0.46 & 0.40 & 0.34 & 0.36 & 0.44 & 0.45 & 0.39 \\
\hline & Majority & Minority & $\begin{array}{l}\text { Education } \\
\text { low: } \\
\text { illiterate }\end{array}$ & $\begin{array}{l}\text { Education } \\
\text { medium: } \\
\text { below Matric }\end{array}$ & $\begin{array}{l}\text { Education } \\
\text { high: Matric } \\
\text { and above }\end{array}$ & $\begin{array}{l}\text { Irrigated } \\
\text { land } \geq \\
\text { dry land }\end{array}$ & $\begin{array}{l}\text { Irrigated } \\
\text { land }< \\
\text { dry land }\end{array}$ \\
\hline \multicolumn{8}{|l|}{ Rural China } \\
\hline $\begin{array}{r}\text { Mean income } \\
\text { (US\$ PPP) }\end{array}$ & 929 & 596 & 861 & 932 & 1095 & 1040 & 664 \\
\hline Population share & 92 & 8 & 11 & 80 & 9 & 64 & 36 \\
\hline Income share & 95 & 5 & 9 & 80 & 11 & 73 & 27 \\
\hline Relative mean & 1.03 & 0.68 & 0.90 & 0.99 & 1.16 & 1.15 & 0.73 \\
\hline $\mathrm{GE}(0)$ & 0.32 & 0.26 & 0.33 & 0.29 & 0.32 & 0.29 & 0.24 \\
\hline $\operatorname{GE}(1)$ & 0.37 & 0.31 & 0.41 & 0.34 & 0.37 & 0.34 & 0.28 \\
\hline Gini & 0.43 & 0.38 & 0.43 & 0.42 & 0.44 & 0.42 & 0.38 \\
\hline
\end{tabular}

US\$ 1 = Rs. 6.64 on PPP basis for India, and US\$ $1=2.56$ yuan for China. 'Matric', in India, represents 10 years of schooling, in China professional school and college graduate.

head: the per-capita income of such persons (US\$ 861) was considerably higher in China than in India (US\$ 561). Similarly, with respect to persons living in households with a moderately educated head - respectively, $80 \%$ of Chinese, and 37\% of Indians - Chinese per-capita income (US\$ 932) was higher than in India (US\$ 710).

In both countries, the average income of persons from a minority community was considerably lower than that of households from the majority community. These income differences were fairly similar across the countries with minority household incomes being, on average, one-third smaller than that of majority households.

Indian rural persons living in land owning households ${ }^{7}$ had a per-capita income (US\$ 768) which was nearly $60 \%$ higher than that of persons in landless households (US\$ 477). Interesting enough this difference is similar to the one in China between households cultivating irrigated land (US\$ 1049) to those cultivating dry land (US\$ 664).

The population subgroups identified in Table 2 may be used to decompose overall inequality in China and in India. Suppose that the sample of $N$ households is divided into $M$ mutually exclusive and collectively exhaustive groups with $N_{m}(m=1, \ldots, M)$ households in each group. Let $\mathbf{y}=\left\{y_{i}\right\}$ and $\mathbf{y}_{m}=\left\{y_{i}\right\}$ represent the vector of incomes for, respectively, all the households in

\footnotetext{
${ }^{7}$ Households who reported that they owned land, however small the holding.
} 
sample $(i=1, \ldots, N)$ and all the households in group $m$. Then an inequality index $I(\mathbf{y} ; N)$ defined over this vector is said to be additively decomposable if:

$$
I(\mathbf{y} ; N)=\sum_{m=1}^{M} I\left(\mathbf{y}_{m} ; N_{m}\right) w_{m}+\mathbf{B}=\mathbf{A}+\mathbf{B}
$$

where $I(\mathbf{y} ; N)$ represents the overall level of inequality; $I\left(\mathbf{y}_{m} ; N_{m}\right)$ the level of inequality within group $m ; \mathbf{A}$ - expressed as the weighted sum of the inequality in each group, $w_{m}$ being the weights - and $\mathbf{B}$ represent, respectively, the within-group and the between-group contribution to overall inequality.

Only inequality indices which belong to the Generalised Entropy (GE) family of indices are additively decomposable (Shorrocks, 1980). These indices are defined by a parameter $\theta$ : when $\theta=0$ the weights are the population shares, and when $\theta=1$ the weights are the income shares, of the subgroups. When $\theta=0$, the inequality index is the Mean Logarithmic Index (Theil, 1967):

$$
\mathrm{GE}(0)=\frac{\sum_{i=1}^{N} \log \left(\mu / y_{i}\right)}{N}
$$

where $\mu$ is the mean income computed over the entire sample.

When $\theta=1$, the inequality index is Theil's Index (Theil, 1967):

$$
\mathrm{GE}(1)=\frac{\sum_{i=1}^{N}\left(y_{i} / \mu\right) \log \left(y_{i} / \mu\right)}{N}
$$

If, indeed, inequality can be 'additively decomposed' along the lines of Eq. (1) above, then, as Cowell and Jenkins (1995) have shown, the proportionate contribution of the between-group component (B) to overall inequality is the income inequality literature's analogue of the $R^{2}$ statistic used in regression analysis: the size of this contribution is a measure of the amount of inequality that can be 'explained' by the factor (or factors) used to subdivide the sample (for example, household's region supply or the educational status of the household head). Further, Zhang and Kanbur (2001) bring forward that this statistics could be used as one (out of several proposed) indicator of the concept 'polarisation'.

Table 3 shows the results for decomposing income inequality in China and in India by different subgroups of population using GE(0) and GE(1), defined above. The most significant feature of the results in Table 3 is that the between-group contributions to inequality, with respect to region, were considerably higher in China than they were in India: using GE(0) as the index of decomposition, $19 \%$ of overall inequality in China, but only $3 \%$ in India, could be 'explained' by differences in mean income between regions. By contrast, $9 \%$ of income inequality in India, compared to $1 \%$ in China, could be explained by differences in the educational status of the household head. Turning to the minority-majority dimension we find that $5 \%$ of income inequality in rural India is due to this dimension while the corresponding proportion in China is only $2 \%$ and alternatively $1 \%$. The background for this is that the size of the minority population is much larger in India while as discussed above the income gap between minorities and the majority is similar in the two countries. Quality of land 'explains' 5\% of income inequality in India, a proportion close to the one for the similar variable in China.

Table 4 shows the income regressions for India and China in which variations in the per-capita income of the households is 'explained' by: region; group membership; and educational status of household head. The estimate of the intercept coefficient is, for India, the estimated average per-capita income of persons who: (a) lived in the eastern region; (b) were landless in the sense of not owning land; (c) belonged to the minority group; (d) had heads who were illiterate. This 
Table 3

The decomposition of income inequality in rural China 1995 and in rural India 1993/1994

\begin{tabular}{|c|c|c|c|c|c|c|c|c|}
\hline & \multicolumn{2}{|c|}{ By region } & \multicolumn{2}{|c|}{$\begin{array}{l}\text { By majority/ } \\
\text { minority }\end{array}$} & \multicolumn{2}{|c|}{$\begin{array}{l}\text { By educational } \\
\text { qualification of } \\
\text { household head }\end{array}$} & \multicolumn{2}{|c|}{ By land ownership } \\
\hline & $\mathrm{GE}(0)$ & GE(1) & $\mathrm{GE}(0)$ & $\mathrm{GE}(1)$ & $\mathrm{GE}(0)$ & $\mathrm{GE}(1)$ & $\mathrm{GE}(0)$ & $\mathrm{GE}(1)$ \\
\hline \multicolumn{9}{|l|}{ Rural India } \\
\hline Overall inequality & 0.35 & 0.39 & 0.35 & 0.39 & 0.35 & 0.39 & 0.35 & 0.39 \\
\hline Within-group inequality & 0.34 & 0.37 & 0.33 & 0.37 & 0.32 & 0.36 & 0.33 & 0.37 \\
\hline Between-group inequality & 0.01 & 0.02 & 0.02 & 0.02 & 0.03 & 0.03 & 0.02 & 0.02 \\
\hline Between-group as percent & 3 & 5 & 5 & 5 & 9 & 8 & 5 & 5 \\
\hline
\end{tabular}
of overall inequality

\begin{tabular}{|c|c|c|c|c|c|c|c|c|}
\hline & \multicolumn{2}{|c|}{ By region } & \multicolumn{2}{|c|}{$\begin{array}{l}\text { By majority/ } \\
\text { minority }\end{array}$} & \multicolumn{2}{|c|}{$\begin{array}{l}\text { By educational } \\
\text { qualification of } \\
\text { household head }\end{array}$} & \multicolumn{2}{|c|}{ By land irrigation } \\
\hline & $\mathrm{GE}(0)$ & $\mathrm{GE}(1)$ & $\mathrm{GE}(0)$ & $\mathrm{GE}(1)$ & $\mathrm{GE}(0)$ & $\mathrm{GE}(1)$ & $\mathrm{GE}(0)$ & $\mathrm{GE}(1)$ \\
\hline \multicolumn{9}{|l|}{ Rural China } \\
\hline Overall inequality & 0.32 & 0.37 & 0.32 & 0.37 & 0.32 & 0.37 & 0.32 & 0.37 \\
\hline Within-group inequality & 0.26 & 0.31 & 0.32 & 0.37 & 0.31 & 0.37 & 0.30 & 0.35 \\
\hline Between-group inequality & 0.06 & 0.06 & 0.01 & 0.005 & 0.002 & 0.002 & 0.02 & 0.02 \\
\hline $\begin{array}{l}\text { Between-group as percent } \\
\text { of overall inequality }\end{array}$ & 19 & 17 & 2 & 1 & 1 & 1 & 7 & 6 \\
\hline
\end{tabular}

was Rs. 1180 (or US\$ 118). This estimate would have been added to by: US\$ 294 for households living in the west; US\$ 276 for land owning households; by US\$ 144 for majority community households; and US\$ 471 for households with a 'well-educated' head. Under these circumstances - representing the most favourable income-generating circumstances - the per-capita income of a household would increase by US\$ 1185 to reach US\$ 1303.

For China, the estimate of the intercept coefficient is the estimated average per-capita income of persons who: (a) lived in the western region; (b) cultivated dry land; (c) belonged to the minority group; (d) have heads who are illiterate. This was 376 yuan or US\$168. This estimate would have been added to by: US\$ 303 for households living in the eastern region; US\$ 69 for households cultivating irrigated land; by US\$ 55 for majority community households; and US\$ 31 for households with a 'well-educated' head. Under these circumstances - representing the most favourable income-generating circumstances - the per-capita income of a household would increase by US\$ 458 to reach US\$ 626. This means that with the exception for region, the marginal return to income-generating factors was much larger in rural India than in rural China. From this follows that when comparing income of persons with given characteristics but living in China and India, respectively, the outcome varies greatly by the characteristics of the person. Pay also attention to the fact that $R^{2}$ in the Chinese sample is considerably smaller than in the Indian sample.

\section{Poverty in rural India and in rural China}

Given a poverty line $z$ and the distribution of incomes represented by the vector $\boldsymbol{y}$, a poverty measure or index is a real valued function $P(y ; z)$ which indicates the level of poverty associated $y$ and $z$. 
Table 4

OLS regression for per-capita household income: rural India 1993/1994 and rural China 1995

\begin{tabular}{|c|c|c|c|c|}
\hline & \multicolumn{2}{|l|}{ India } & \multicolumn{2}{|l|}{ China } \\
\hline & $\begin{array}{l}\text { Per-capita } \\
\text { household } \\
\text { income (Rs.) }\end{array}$ & $\begin{array}{l}\text { Per-capita } \\
\text { household } \\
\text { income (US\$) }\end{array}$ & $\begin{array}{l}\text { Per-capita } \\
\text { household } \\
\text { income (Yuan) }\end{array}$ & $\begin{array}{l}\text { Per-capita } \\
\text { household } \\
\text { income (US\$) }\end{array}$ \\
\hline Central & $351.4(9.2)$ & 52.9 & $104.4(7.8)$ & 50.5 \\
\hline South (India only) & $1591.5(37.1)$ & 239.7 & NA & NA \\
\hline West & $1952.5(41.0)$ & 294.1 & Residual region & Residual region \\
\hline North (India only) & $1484.4(30.3)$ & 223.6 & NA & NA \\
\hline East & Residual region & Residual region & $714.3(51.3)$ & 303.0 \\
\hline Majority & $954.2(36.8)$ & 143.7 & $117.5(5.9)$ & 54.8 \\
\hline Land-owner (India only) & $1830.1(66.1)$ & 275.6 & NA & NA \\
\hline $\begin{array}{l}\text { Irrigated land } \geq \text { dry } \\
\text { land (China only) }\end{array}$ & NA & NA & $177.5(16.1)$ & 69.3 \\
\hline HoH medium education & $682.1(25.0)$ & 102.7 & Dropped & Dropped \\
\hline HoH high education & $3123.9(79.1)$ & 470.5 & $70.2(3.3)$ & 30.7 \\
\hline Intercept & $1179.9(29.3)$ & 117.7 & $375.9(17.0)$ & 167.7 \\
\hline
\end{tabular}

Notes:

1. Figures in parentheses represent $t$-values.

2. The estimate on the intercept term, in the equation for India, is the estimated per-capita annual income of a person (in rupees and in dollars) who: (a) lives in the east; (b) is landless; (c) belongs to the minority group; (d) has a household head with 'low' educational qualifications.

3. The estimate on the intercept term, in the equation for China, is the estimated per-capita annual income of a person (in yuan and in dollars) who: (a) lives in the west; (b) for whom irrigated area $<$ dry land; (c) belongs to the minority group; (d) has a household head with 'low' educational qualifications.

4. The other estimates represent the increment to household per-capita annual income when one of the conditions (a-d) is relaxed.

5. $\bar{R}^{2}=0.45, N=187,299$ in equation for India; $\bar{R}^{2}=0.127, N=34,701$ in equation for China.

Suppose that of $N$ households, with incomes $y_{i}, i=1, \ldots, N$ arranged in ascending order, $M$ households are poor in the sense of having incomes at or below the poverty, $z$.

In order to analyse the decomposition of poverty, suppose that, given a poverty line $z$, there are $M$ poor households in the total of $N$ households and that, in group $k, M_{k}$, of the $N_{k}$, households in the group, are poor $(k=1, \ldots, K)$. Let $\mathbf{y}=\left\{y_{i}\right\}$ and $\mathbf{y}_{k}=\left\{y_{i}\right\}$ now represent the vector of incomes of, respectively, all the poor households in the sample $(i=1, \ldots, M)$ and the poor households in group $k\left(k=1, \ldots, M_{k}\right)$. Then the poverty index due to Foster, Greer, and Thorbecker (1984) is defined, for a parameter $\alpha \geq 0$, as:

$$
\operatorname{FGT}(\mathbf{y} ; \alpha)=\frac{\sum_{i=1}^{K}\left(z-y_{i}\right)^{\alpha}}{N z^{\alpha}}
$$

When $\alpha=0$, the FGT index is the Head Count Ratio, $H=M / N$; when $\alpha=1, \operatorname{FGT}(\mathbf{y} ; 1)=H R$, where $R=1-\mu / z$ is the Poverty Gap Ratio; when $\alpha=2$, the FGT index incorporates the idea of 'relative deprivation', as measured by income inequality among the poor households, since: $\operatorname{FGT}(\mathbf{y} ; 1)=H\left[R^{2}+(1-R)^{2}\right] \Phi$, where $\Phi$ is the (square of) the coefficient of variation, computed over the incomes of poor households. 
Table 5

Poverty in rural India 1993/1994 and rural China 1995

\begin{tabular}{|c|c|c|c|c|c|c|}
\hline & \multicolumn{2}{|c|}{$\begin{array}{l}\text { Poverty line is } 1 / 2 \\
\text { median income of } \\
\text { rural part of country }\end{array}$} & \multicolumn{2}{|c|}{$\begin{array}{l}\text { Poverty line is } 2 / 3 \\
\text { median income of } \\
\text { rural part of country }\end{array}$} & \multicolumn{2}{|c|}{$\begin{array}{l}\text { Poverty line is US\$ } \\
1 \text { per day at PPP }\end{array}$} \\
\hline & India & China & India & China & India & China \\
\hline Head Count Ratio & 17.2 & 12.4 & 29.4 & 25.3 & 36.7 & 17.6 \\
\hline Poverty Gap Ratio & 5.5 & 3.2 & 9.9 & 7.1 & 13.1 & 4.6 \\
\hline Income Gap Ratio & 31.6 & 25.7 & 33.8 & 28.2 & 35.7 & 26.1 \\
\hline Sen index & 7.6 & 4.5 & 13.7 & 9.9 & 17.8 & 6.5 \\
\hline FGT(2) index & 2.6 & 1.3 & 4.8 & 3.0 & 6.5 & 1.8 \\
\hline FGT(3) index & 1.5 & 0.6 & 2.8 & 1.5 & 3.8 & 0.9 \\
\hline
\end{tabular}

An attractive feature of the FGT poverty index is that it is decomposable in the sense that the value of the overall index can be expressed as the weighted average of the subgroup values:

$$
\operatorname{FGT}(\mathbf{y} ; \alpha)=\sum_{k=1}^{K} v_{k} \times \operatorname{FGT}\left(\mathbf{y}_{k} ; \alpha\right)
$$

where $v_{k}=N_{k} / N$ is the population share of group $k$.

The proportionate contribution made by group $k$ to overall poverty is then:

$$
C_{k}=\frac{v_{k} \times \operatorname{FGT}\left(\mathbf{y}_{k} ; \alpha\right)}{\operatorname{FGT}(\mathbf{y} ; \alpha)}
$$

and the 'poverty risk' of a group is:

$$
\rho_{k}=\frac{\operatorname{FGT}\left(\mathbf{y}_{k} ; \alpha\right)}{\operatorname{FGT}(\mathbf{y} ; \alpha)}=\frac{\operatorname{FGT}\left(\mathbf{y}_{k} ; \alpha\right) C_{k}}{v_{k} \operatorname{FGT}\left(\mathbf{y}_{k} ; \alpha\right)}=\frac{C_{k}}{v_{k}}
$$

The poverty risk thus is the ratio of a group's contribution to poverty in a region to its contribution to the population of that region: $\rho_{k}>1\left(\rho_{k}<1\right)$ means that it contributes more (less) to poverty than its population share warrants. If the norm for poverty risk is taken to be unity, then, say, $\rho_{k}=1.3$ means that the poverty risk for members of group $k$ is $30 \%$ above the norm; similarly, $\rho_{k}=0.82$ means that the poverty risk for members of group $k$ is $18 \%$ below the norm.

Table 5 shows that on all measures of poverty, and for every poverty line, the incidence of poverty was greater in rural India than in rural China: with a poverty line of US\$ 1 per day, less than one-fifth of Chinese households compared to over one-third of Indian households were poor; the mean income shortfall of poor households, on the US\$ 1 per day poverty line, was $4.6 \%$ in China and $13.1 \%$ in India; when relative deprivation was taken into account, using the Sen index ${ }^{8}$ or the FGT(2) index, China continued to show a lower level of poverty than India.

These conclusions were not altered when the focus was on selected subgroups of the population in, respectively, India and China. On a US\$ 1 per day poverty line, over half of all landless households in India were poor as were: $40 \%$ of all households in the central region and $46 \%$ of households in the eastern region; $41 \%$ of all minority households; and $43 \%$ of all households in

${ }^{8}$ See Sen (1976). 
which the head was illiterate. By contrast, in China, just over a third of minority households were poor and, in the poorest western region, just over one-third of households were poor.

The poverty decompositions for India and China are shown in Tables 6 and 7, respectively. It turns out that results are not sensitive to how the poverty line is specified. The subgroups for which the decompositions were done are: region; majority/minority groups; land-owners/ landless; and educational level of head. For India, using a US\$ 1 per day poverty, with the Head Count Ratio as the poverty measure, the 'poverty risk', as defined by Eq. (6), was highest in the central and the eastern region: their respective poverty risks were $8 \%$ and $26 \%$ above the norm; by contrast, the poverty risk, at $24 \%$ below the norm, was lowest in the north. In China, as Table 7 shows, the poverty risk, calculated using the Head Count Measure, in the poorest (western) region was $102 \%$ above the norm.

Households from the minority group and landless households made, relative to their share in the sample, a disproportionate contribution to poverty in India: on a US\$ 1 per day poverty line, using the Head Count Ratio, the respective poverty risks of minority group households and of households with illiterate heads were both $20 \%$ above the norm and the poverty risk of landless households was $40 \%$ above the norm. In China, as Table 7 shows, the poverty risk of minority households was $90 \%$ above the norm and that of households with an illiterate head was $46 \%$ above the norm.

\section{The determinants of poverty in China and India}

In this section we model factors that determine poverty status in rural China and rural India. Table 8 shows, for India and China, results from logit regressions in which the dependent variable, $Y$, was defined so that $Y_{i}=1$ if household $i$ was poor and $Y_{i}=0$ if it was not. The variables used to explain the likelihood of a household being poor were: the region in which it lived; whether it belonged to the majority or minority group; whether it was land owning or landless (for India); whether the land it cultivated was largely irrigated or dry (China); and the education level of its head.

Shown parenthetically, alongside the coefficient estimates in Table 8, are the marginal probabilities associated with the estimates. These represent the increase $(+) /$ decrease $(-)$ in the probability of being poor, for a unit change in the value of the relevant variable, the values of the other variables being set to their means. For 0/1 variables - as, indeed, are all the variables in the regression - a unit change represents a change from the relevant default category (north; minority; illiterate; and landless) to the category in question.

The marginal probabilities of a household being poor, associated with the regions of India, were all positive: with the values of all the non-regional variables set to the omitted category, the average probability of a household being poor was lowest in the north. On the other hand, the marginal probabilities associated with the educational levels shown in Table 8 were all negative: with the values of all the non-educational variables set to the omitted category, the average probability of a household being poor - on a US\$ 1 per day poverty line - was 8.3 percentage points (hereafter, simply 'points') lower for households with 'moderately educated' heads - and 24.5 points lower for households with 'well-educated' heads - compared to households with illiterate heads.

The marginal probabilities associated with being a household from the majority group, and with being a land owning household, were also negative implying that belonging to the majority community and to a land owning household reduced the probability of being poor. This reduction, on a US\$ 1 per day poverty line, was 7.5 points for majority households and 20.7 points for land owning households. 
Table 6

The decomposition of poverty in rural India 1993/1994, FGT $(\alpha) \times 100$

\begin{tabular}{|c|c|c|c|c|c|c|c|c|c|}
\hline & \multicolumn{3}{|l|}{$\alpha=0$} & \multicolumn{3}{|l|}{$\alpha=1$} & \multicolumn{3}{|l|}{$\alpha=2$} \\
\hline & $\begin{array}{l}1 / 2 \text { rural } \\
\text { median }\end{array}$ & $\begin{array}{l}2 / 3 \text { rural } \\
\text { median }\end{array}$ & $\begin{array}{l}\text { US\$ } 1 \\
\text { per day }\end{array}$ & $\begin{array}{l}1 / 2 \text { rural } \\
\text { median }\end{array}$ & $\begin{array}{l}2 / 3 \text { rural } \\
\text { median }\end{array}$ & $\begin{array}{l}\text { US\$ } 1 \\
\text { per day }\end{array}$ & $\begin{array}{l}1 / 2 \text { rural } \\
\text { median }\end{array}$ & $\begin{array}{l}2 / 3 \text { rural } \\
\text { median }\end{array}$ & $\begin{array}{l}\text { US\$ } 1 \\
\text { per day }\end{array}$ \\
\hline Overall poverty & 17.2 & 29.4 & 36.7 & 5.5 & 9.9 & 13.1 & 2.6 & 4.8 & 6.5 \\
\hline \multicolumn{10}{|c|}{ Contribution to overall poverty by region (\%) } \\
\hline Central $[40.5]$ & $42.1(17.9)$ & $43.7(31.9)$ & $43.7(39.5)$ & $41.0(5.5)$ & $42.2(10.5)$ & $42.7(13.8)$ & $40.7(2.6)$ & $41.4(50.0)$ & $41.9(6.8)$ \\
\hline South [20.3] & $19.8(16.8)$ & $18.5(26.9)$ & $18.3(33.0)$ & $20.5(5.5)$ & $19.5(9.6)$ & $19.1(12.3)$ & $20.9(2.7)$ & $20.2(48.6)$ & $19.8(6.4)$ \\
\hline West [13.0] & $11.1(14.6)$ & $11.0(25.1)$ & $11.2(31.6)$ & $10.3(4.3)$ & $10.8(8.3)$ & $10.9(11.0)$ & $9.4(1.9)$ & $10.2(38.5)$ & $10.5(5.3)$ \\
\hline East [14.3] & $18.9(22.8)$ & $18.0(37.2)$ & $17.8(45.7)$ & $20.4(7.8)$ & $19.2(13.5)$ & $18.8(17.2)$ & $21.3(3.9)$ & $20.2(6.9)$ & $19.6(9.0)$ \\
\hline North [11.8] & $8.1(11.9)$ & $8.8(21.9)$ & $9.0(27.9)$ & $7.8(3.6)$ & $8.3(7.0)$ & $8.5(9.4)$ & $7.7(1.7)$ & $8.0(3.3)$ & $8.2(4.5)$ \\
\hline \multicolumn{10}{|c|}{ Contribution to overall poverty by majority/minority (\%) } \\
\hline Majority [53.8] & $43.1(13.8)$ & $43.6(23.9)$ & $43.9(29.9)$ & $44.4(4.5)$ & $43.8(8.2)$ & $43.7(10.6)$ & $45.2(2.2)$ & $44.3(4.0)$ & $44.1(5.4)$ \\
\hline Minority [46.2] & $56.9(21.2)$ & $56.4(36.1)$ & $56.1(44.5)$ & $55.6(6.6)$ & $56.2(12.2)$ & $56.3(15.9)$ & $54.8(3.1)$ & $55.7(5.9)$ & $55.9(7.9)$ \\
\hline \multicolumn{10}{|c|}{ Contribution to overall poverty by education of $\mathrm{HoH}(\%)$} \\
\hline Low $[50.0]$ & $60.7(20.9)$ & $60.6(35.8)$ & $59.9(43.9)$ & $59.8(6.5)$ & $60.4(12.1)$ & $60.4(15.8)$ & $59.4(3.1)$ & $60.0(5.9)$ & $60.2(7.9)$ \\
\hline Medium [37.4] & $33.4(15.4)$ & $33.8(26.8)$ & $34.2(33.6)$ & $34.2(5.0)$ & $33.7(9.1)$ & $33.8(11.8)$ & $34.5(2.4)$ & $34.1(4.4)$ & $33.9(5.9)$ \\
\hline High [12.6] & $5.9(8.1)$ & $5.6(13.2)$ & $5.9(17.0)$ & $5.8(2.6)$ & $5.8(4.6)$ & $5.8(6.0)$ & $6.1(1.2)$ & $5.9(2.3)$ & $5.9(3.1)$ \\
\hline \multicolumn{10}{|c|}{ Contribution to overall poverty by land-owner/landless } \\
\hline Land-owner [70.0] & $56.0(13.8)$ & $57.3(24.3)$ & $58.1(30.4)$ & $54.2(4.2)$ & $55.7(8.0)$ & $56.4(10.1)$ & $53.1(4.0)$ & $54.5(3.8)$ & $55.1(5.2)$ \\
\hline Landless [30.0] & $44.0(25.2)$ & $42.7(42.0)$ & $41.9(51.1)$ & $45.8(8.3)$ & $44.3(14.8)$ & $43.6(18.9)$ & $46.9(2.0)$ & $45.5(7.4)$ & $44.8(9.8)$ \\
\hline
\end{tabular}

Figures in [ ] represent the proportion of the sample in that subgroup. Figures in ( ) represent the FGT value for the subgroup. 
Table 7

The decomposition of poverty in rural China 1995, FGT $(\alpha) \times 100$

\begin{tabular}{|c|c|c|c|c|c|c|c|c|c|}
\hline & \multicolumn{3}{|l|}{$\alpha=0$} & \multicolumn{3}{|l|}{$\alpha=1$} & \multicolumn{3}{|l|}{$\alpha=2$} \\
\hline & $\begin{array}{l}1 / 2 \text { rural } \\
\text { median }\end{array}$ & $\begin{array}{l}2 / 3 \text { rural } \\
\text { median }\end{array}$ & $\begin{array}{l}\text { US\$ } 1 \\
\text { per day }\end{array}$ & $\begin{array}{l}1 / 2 \text { rural } \\
\text { median }\end{array}$ & $\begin{array}{l}2 / 3 \text { rural } \\
\text { median }\end{array}$ & $\begin{array}{l}\text { US\$ } 1 \\
\text { per day }\end{array}$ & $\begin{array}{l}1 / 2 \text { rural } \\
\text { median }\end{array}$ & $\begin{array}{l}2 / 3 \text { rural } \\
\text { median }\end{array}$ & $\begin{array}{l}\text { US\$ } 1 \\
\text { per day }\end{array}$ \\
\hline Overall poverty & 12.4 & 25.3 & 17.6 & 3.2 & 7.1 & 4.6 & 1.3 & 3.0 & 1.8 \\
\hline \multicolumn{10}{|c|}{ Contribution to overall poverty by region (\%) } \\
\hline Central [38.0] & $34.5(11.3)$ & $35.3(23.5)$ & $35.4(16.4)$ & $34.4(2.9)$ & $35.3(6.6)$ & $34.7(4.2)$ & $35.3(1.2)$ & $34.3(2.7)$ & $35.9(1.7)$ \\
\hline West [25.7] & $53.5(25.8)$ & $49.2(48.4)$ & $51.8(35.5)$ & $53.8(6.7)$ & $52.8(14.6)$ & $53.5(9.5)$ & $53.4(2.7)$ & $53.5(6.2)$ & $55.7(3.9)$ \\
\hline East [36.3] & $12.0(4.1)$ & $15.5(10.8)$ & $12.8(6.2)$ & $11.8(1.0)$ & $12.8(2.5)$ & $11.8(1.5)$ & $11.2(0.4)$ & $12.2(1.0)$ & $12.1(0.6)$ \\
\hline \multicolumn{10}{|c|}{ Contribution to overall poverty by majority/minority (\%) } \\
\hline Majority [92.3] & $85.1(11.5)$ & $86.1(23.7)$ & $85.4(16.3)$ & $86.0(3.0)$ & $85.5(6.6)$ & $86.0(4.3)$ & $85.3(1.2)$ & $86.1(2.8)$ & $87.2(1.7)$ \\
\hline Minority [7.7] & $15.0(24.4)$ & $13.9(45.7)$ & $14.7(33.5)$ & $14.1(6.1)$ & $14.6(13.5)$ & $14.1(8.8)$ & $14.6(2.3)$ & $14.0(5.6)$ & $14.5(3.4)$ \\
\hline \multicolumn{10}{|c|}{ Contribution to overall poverty by land type (\%) } \\
\hline Irrigated land $\geq$ dry land [63.8] & $39.6(7.7)$ & $45.6(18.1)$ & $41.7(11.5)$ & $36.3(1.8)$ & $41.0(4.6)$ & $38.6(2.8)$ & $34.9(0.7)$ & $38.4(1.8)$ & $35.4(1.0)$ \\
\hline Irrigated land < dry land [36.2] & $60.4(20.7)$ & $54.4(37.9)$ & $58.2(28.3)$ & $63.6(5.6)$ & $59.1(11.7)$ & $61.4(7.8)$ & $65.0(2.3)$ & $61.5(5.1)$ & $64.4(3.2)$ \\
\hline \multicolumn{10}{|c|}{ Contribution to overall poverty by education of $\mathrm{HoH}(\%)$} \\
\hline Low [10.9] & $17.8(20.2)$ & $14.7(34.1)$ & $15.9(25.7)$ & $18.7(5.5)$ & $16.9(11.0)$ & $18.0(7.6)$ & $19.7(2.3)$ & $17.8(4.9)$ & $20.0(3.3)$ \\
\hline Medium [79.8] & $74.7(11.6)$ & $77.3(24.5)$ & $75.5(16.6)$ & $72.3(2.9)$ & $75.2(6.7)$ & $74.3(4.3)$ & $73.7(1.2)$ & $71.8(2.7)$ & $75.4(1.7)$ \\
\hline High [9.3] & $7.8(10.4)$ & $7.9(20.7)$ & $8.6(15.8)$ & $7.1(2.5)$ & $7.9(6.0)$ & $7.7(3.8)$ & $6.6(0.9)$ & $7.4(2.4)$ & $7.2(1.4)$ \\
\hline
\end{tabular}

Figures in [ ] represent the proportion of the sample in that subgroup. Figures in ( ) represent the FGT value for the subgroup. 
Table 8

Logit regressions for the likelihood of being poor: rural India 1993/1994 and rural China 1995

\begin{tabular}{|c|c|c|c|c|c|c|}
\hline & \multicolumn{3}{|l|}{ India } & \multicolumn{3}{|l|}{ China } \\
\hline & $\begin{array}{l}\text { Poverty line is } \\
1 / 2 \text { median income }\end{array}$ & $\begin{array}{l}\text { Poverty line is } \\
2 / 3 \text { median income }\end{array}$ & $\begin{array}{l}\text { Poverty line is US\$ } \\
1 \text { per day (PPP) }\end{array}$ & $\begin{array}{l}\text { Poverty line is } \\
1 / 2 \text { median income }\end{array}$ & $\begin{array}{l}\text { Poverty line is } \\
2 / 3 \text { median income }\end{array}$ & $\begin{array}{l}\text { Poverty line is US\$ } \\
1 \text { per day (PPP) }\end{array}$ \\
\hline Central & $1.702[0.074](22.9)$ & $1.786[0.118](30.9)$ & $1.843[0.141](34.8)$ & $0.435[-0.067](-21.8)$ & $0.380[-0.156](-31.6)$ & $0.418[-0.099](-25.9)$ \\
\hline South & $1.470[0.056](15.3)$ & $1.289[0.052](12.3)$ & $1.252[0.052](11.6)$ & & & \\
\hline West & $1.349[0.043](10.7)$ & $1.268[0.049](10.4)$ & $1.284[0.058](11.7)$ & & & \\
\hline East & $2.261[0.131](31.4)$ & $2.228[0.177](37.2)$ & $2.334[0.204](41.5)$ & $0.170[-0.133](-33.2)$ & $0.171[-0.266](-47.3)$ & $0.163[-0.192](-40.4)$ \\
\hline Majority & $0.773[-0.035](-19.7)$ & $0.744[-0.059](-27.2)$ & $0.719[-0.075](-31.8)$ & $0.709[-0.033](-6.6)$ & $0.673[-0.074](-8.7)$ & $0.691[-0.050](-7.7)$ \\
\hline Land-owner & $0.488[-0.106](-54.8)$ & $0.440[-0.175](-72.7)$ & $0.414[-0.207](-80.0)$ & NA & NA & NA \\
\hline $\begin{array}{l}\text { Irrigated } \\
\quad \text { land } \geq \\
\text { dry land }\end{array}$ & NA & NA & NA & $0.472[-0.071](-21.3)$ & $0.529[-0.115](-23.4)$ & $0.485[-0.095](-23.6)$ \\
\hline $\begin{array}{l}\text { HoH medium } \\
\text { education }\end{array}$ & $0.726[-0.042](-23.4)$ & $0.697[-0.071](-31.5)$ & $0.690[-0.083](-33.9)$ & $0.763[-0.025](-6.2)$ & $0.868[-0.025](-3.9)$ & $0.824[-0.024](-4.9)$ \\
\hline $\begin{array}{l}\text { HoH high } \\
\text { education }\end{array}$ & $0.346[-0.108](-41.3)$ & $0.279[-0.198](-60.7)$ & $0.266[-0.245](-69.1)$ & $0.796[-0.018](-3.1)$ & $0.808[-0.035](-3.7)$ & $0.926[-0.009](-1.2)$ \\
\hline Pseudo- $R^{2}$ & 0.045 & 0.064 & 0.073 & 0.108 & 0.116 & 0.116 \\
\hline $\begin{array}{l}\text { Number of } \\
\text { observations }\end{array}$ & 187,299 & 187,299 & 187,299 & 34,701 & 34,701 & 34,701 \\
\hline Log-likelihood & $-82,233.6$ & $-106,193.1$ & $-114,050.4$ & $-11,610.2$ & $-17,343.9$ & $-14,262.3$ \\
\hline
\end{tabular}

Notes:

1. $Y_{i}=1$ if household is poor; $Y_{i}=0$ if household is not poor.

2. Coefficients represent the change in the odds-ratio, $\operatorname{Pr}(Y=1) / \operatorname{Pr}(Y=0)$, given a unit change in the variable.

3. Figures in parentheses [ ] are marginal probabilities. These represent the increase (+)/decrease ( -$)$ in the probability of being poor, for a unit change in the value of the relevant variable, the values of the other variables being set their mean value. For 0/1 variables, a unit change represents a change from the default category (north/illiterate/landless) to the category in question.

4. Figures in parentheses ( ) are $z$-scores. 
Turning to the results for China, it is not surprising that the marginal probability for people being poor in the eastern regions was lowest and for those in the western regions was highest whichever poverty line was applied. For a poverty line of US\$ 1 per day, the average probability of the western Chinese falling into poverty was 10 points higher than their compatriots in the central part, and 19 points higher than their compatriots in the eastern part, other things being equal. This result indicates again that China's poverty was more concentrated on the western part and less severe in the eastern part. China had a quite similar pattern of poverty associated with ethnic minorities with India. In the western regions, being an ethnic minority, the marginal probability being poor was 5-7 points higher than Han majority. Unlike the results for India, education had much smaller impact on poverty status in China. The average probability of people being poor was only 2.4 points lower for those with 'moderately educated' heads, compared to those with illiterate heads. Surprisingly, there was no significant difference in the average probability to fall below a poverty line set equal to US\$ 1 per day between those with illiterate heads and those with 'well-educated' heads. The results in Table 8 show that land irrigation made significant impact on poverty reduction. For those households having irrigated land greater than dry land had lower probability to fall into poverty by around 10 points than those having less irrigated land.

The probabilities of being poor under different scenarios, relating to the circumstances of the households, are shown, for a poverty line of US\$ 1 per day, in Table 9 for India and in Table 10 for China. The assumption underlying the figures in Tables 9 and 10 is that all the households lived in the circumstances outlined in the scenario. For example, in Scenario 1 of Table 9, the average, 'all-India' likelihood of landless, minority group households with an illiterate head being poor, at a US\$ 1 per day poverty line, was $61.8 \%$ : in computing this likelihood, it was assumed that the regional distribution of the households was as in the sample. ${ }^{9}$ However, if it was assumed that all such households lived, say, in the north, then, with all households living in the north and also being landless, minority group households with an illiterate head, the average likelihood of being poor would be $51.1 \%$.

The difference between two scenarios reflects the change in the probability of being poor that stems from the change in the circumstances underlying the two scenarios. Since nothing else was changed between the two scenarios, the change in the probability maybe ascribed entirely to the change in circumstance. For example, in Table 9, comparing Scenario 1 with Scenario 4, the fall in the probability of being poor from $61.8 \%$ to $53.9 \%$ may be ascribed to the majority group effect on landless households with an illiterate head; comparing Scenarios 9 and 12, the fall in the probability of being poor from $15.6 \%$ to $11.7 \%$ may be ascribed to the majority group effect on land owning households with a well-educated head.

From Table 9 it is clear that, in India, the effects of higher education levels on reducing the likelihood of being poor were stronger than the effects of belonging to the majority group: for a minority group landless household with a well-educated head, the average likelihood of being poor was $30.6 \%$ compared to $61.8 \%$ for a minority group landless household with an illiterate head (Scenarios 3 and 1); for a majority group landless household with a well-educated head, the average likelihood of being poor was $24.1 \%$ compared to $53.9 \%$ for a majority group landless household with an illiterate head (Scenarios 6 and 4).

Land ownership too dramatically affected the chances of household being poor: for majority group households with a well-educated head the average likelihood of being poor was $11.7 \%$ if it

\footnotetext{
${ }^{9}$ Twelve percent north; $41 \%$ central; $20 \%$ south; $13 \%$ west; $14 \%$ east.
} 
Table 9

Estimated probabilities of being poor, by region: rural India 1993/1994; poverty line US\$ 1 per day

\begin{tabular}{|c|c|c|c|c|c|c|c|}
\hline \multicolumn{2}{|c|}{ Scenario } & \multicolumn{6}{|c|}{ Probability } \\
\hline & & \multirow{2}{*}{$\begin{array}{l}\text { All-India } \\
61.8\end{array}$} & \multirow{2}{*}{$\begin{array}{l}\text { North } \\
51.1\end{array}$} & \multirow{2}{*}{$\begin{array}{l}\text { West } \\
57.3\end{array}$} & \multirow{2}{*}{$\begin{array}{l}\text { South } \\
56.6\end{array}$} & \multirow{2}{*}{$\begin{array}{l}\text { Central } \\
65.8\end{array}$} & \multirow{2}{*}{$\frac{\text { East }}{70.9}$} \\
\hline 1 & $\begin{array}{l}\text { All persons: } \\
\text { Belong to minority group } \\
\text { Are landless } \\
\text { Have HoH with low education level }\end{array}$ & & & & & & \\
\hline 2 & $\begin{array}{l}\text { All persons: } \\
\text { Belong to minority group } \\
\text { Are landless } \\
\text { Have HoH with medium education level }\end{array}$ & 52.9 & 41.9 & 48.0 & 47.4 & 57.0 & 62.7 \\
\hline 3 & $\begin{array}{l}\text { All persons: } \\
\text { Belong to minority group } \\
\text { Are landless } \\
\text { Have HoH with high education level }\end{array}$ & 30.6 & 21.7 & 26.3 & 25.8 & 33.8 & 39.3 \\
\hline 4 & $\begin{array}{l}\text { All persons: } \\
\text { Belong to majority group } \\
\text { Are landless } \\
\text { Have HoH with low education level }\end{array}$ & 53.9 & 42.9 & 49.1 & 48.4 & 58.0 & 63.7 \\
\hline 5 & $\begin{array}{l}\text { All persons: } \\
\text { Belong to majority group } \\
\text { Are landless } \\
\text { Have HoH with medium education level }\end{array}$ & 44.8 & 34.1 & 39.9 & 39.3 & 48.8 & 54.7 \\
\hline 6 & $\begin{array}{l}\text { All persons: } \\
\text { Belong to majority group } \\
\text { Are landless } \\
\text { Have HoH with high education level }\end{array}$ & 24.1 & 16.6 & 20.3 & 20.0 & 26.9 & 31.8 \\
\hline 7 & $\begin{array}{l}\text { All persons: } \\
\text { Belong to minority group } \\
\text { Are land-owners } \\
\text { Have HoH with low education level }\end{array}$ & 40.5 & 30.2 & 35.7 & 35.1 & 44.3 & 50.2 \\
\hline 8 & $\begin{array}{l}\text { All persons: } \\
\text { Belong to minority group } \\
\text { Are land-owners } \\
\text { Have HoH with medium education level }\end{array}$ & 32.1 & 23.0 & 27.7 & 27.2 & 35.4 & 41.1 \\
\hline 9 & $\begin{array}{l}\text { All persons: } \\
\text { Belong to minority group } \\
\text { Are land-owners } \\
\text { Have HoH with high education level }\end{array}$ & 15.6 & 10.3 & 12.9 & 12.6 & 17.5 & 21.1 \\
\hline 10 & $\begin{array}{l}\text { All persons: } \\
\text { Belong to majority group } \\
\text { Are land-owners } \\
\text { Have HoH with low education level }\end{array}$ & 33.0 & 23.7 & 28.5 & 28.0 & 36.4 & 42.1 \\
\hline 11 & $\begin{array}{l}\text { All persons: } \\
\text { Belong to majority group } \\
\text { Are land-owners } \\
\text { Have HoH with medium education level }\end{array}$ & 25.5 & 17.7 & 21.6 & 21.2 & 28.3 & 33.4 \\
\hline 12 & $\begin{array}{l}\text { All persons: } \\
\text { Belong to majority group } \\
\text { Are land-owners } \\
\text { Have HoH with high education level }\end{array}$ & 11.7 & 7.6 & 9.6 & 9.4 & 13.2 & 16.2 \\
\hline
\end{tabular}


Table 10

Estimated probabilities of being poor, by region: rural China 1995; poverty line US\$ 1 per day

\begin{tabular}{|c|c|c|c|c|c|}
\hline \multicolumn{2}{|c|}{ Scenario } & \multicolumn{4}{|l|}{ Probability } \\
\hline & & \multirow{2}{*}{$\begin{array}{l}\text { All-China } \\
31.9\end{array}$} & \multirow{2}{*}{$\begin{array}{l}\text { West } \\
53.7\end{array}$} & \multirow{2}{*}{$\begin{array}{l}\text { Central } \\
32.6\end{array}$} & \multirow{2}{*}{$\begin{array}{l}\text { East } \\
7.3\end{array}$} \\
\hline 1 & $\begin{array}{l}\text { All persons: } \\
\text { Belong to minority group } \\
\text { With irrigated land }<\text { dry land } \\
\text { Have HoH with low education level }\end{array}$ & & & & \\
\hline 2 & $\begin{array}{l}\text { All persons: } \\
\text { Belong to minority group } \\
\text { With irrigated land }<\text { dry land } \\
\text { Have HoH with medium education level }\end{array}$ & 29.1 & 50.0 & 29.5 & 6.4 \\
\hline 3 & $\begin{array}{l}\text { All persons: } \\
\text { Belong to minority group } \\
\text { With irrigated land }<\text { dry land } \\
\text { Have HoH with high education level }\end{array}$ & 31.8 & 53.5 & 32.1 & 7.0 \\
\hline 4 & $\begin{array}{l}\text { All persons: } \\
\text { Belong to majority group } \\
\text { With irrigated land }<\text { dry land } \\
\text { Have HoH with low education level }\end{array}$ & 25.7 & 45.1 & 25.6 & 5.3 \\
\hline 5 & $\begin{array}{l}\text { All persons: } \\
\text { Belong to majority group } \\
\text { With irrigated land }<\text { dry land } \\
\text { Have HoH with medium education level }\end{array}$ & 23.3 & 41.5 & 23.0 & 4.6 \\
\hline 6 & $\begin{array}{l}\text { All persons: } \\
\text { Belong to majority group } \\
\text { With irrigated land }<\text { dry land } \\
\text { Have HoH with high education level }\end{array}$ & 25.6 & 44.9 & 25.5 & 5.3 \\
\hline 7 & $\begin{array}{l}\text { All persons: } \\
\text { Belong to minority group } \\
\text { With irrigated land } \geq \text { dry land } \\
\text { Have HoH with low education level }\end{array}$ & 24.6 & 42.4 & 23.9 & 5.0 \\
\hline 8 & $\begin{array}{l}\text { All persons: } \\
\text { Belong to minority group } \\
\text { With irrigated land } \geq \text { dry land } \\
\text { Have HoH with medium education level }\end{array}$ & 22.3 & 38.9 & 21.4 & 4.4 \\
\hline 9 & $\begin{array}{l}\text { All persons: } \\
\text { Belong to minority group } \\
\text { With irrigated land } \geq \text { dry land } \\
\text { Have HoH with high education level }\end{array}$ & 24.5 & 42.2 & 23.8 & 4.9 \\
\hline 10 & $\begin{array}{l}\text { All persons: } \\
\text { Belong to majority group } \\
\text { With irrigated land } \geq \text { dry land } \\
\text { Have HoH with low education level }\end{array}$ & 19.6 & 34.5 & 18.4 & 3.6 \\
\hline 11 & $\begin{array}{l}\text { All persons: } \\
\text { Belong to majority group } \\
\text { With irrigated land } \geq \text { dry land } \\
\text { Have HoH with medium education level }\end{array}$ & 17.7 & 31.4 & 16.4 & 3.2 \\
\hline 12 & $\begin{array}{l}\text { All persons: } \\
\text { Belong to majority group } \\
\text { With irrigated land } \geq \text { dry land } \\
\text { Have HoH with high education level }\end{array}$ & 19.5 & 34.4 & 18.4 & 3.6 \\
\hline
\end{tabular}


owned land (Scenario 12) and $24.1 \%$ if it was landless (Scenario 6); for minority group households with an illiterate head the average likelihood of being poor was $40.5 \%$ if it owned land (Scenario 7) and 61.8\% if it was landless (Scenario 1).

By contrast, the effect of belonging to the majority group on the likelihood of being poor was much more muted: for land owning households with a well-educated head the average likelihood of being poor was $15.6 \%$ if the household belonged to the minority group (Scenario 9) and 11.7\% if it belonged to the majority group (Scenario 12); for landless households with an illiterate head the average likelihood of being poor was $61.8 \%$ if the household belonged to the minority group (Scenario 1) and $53.9 \%$ if it belonged to the majority group (Scenario 4).

Table 10 presents the simulation results for the Chinese scenarios. It is clear that region play a very important role in poverty incidence. For the minority people having lower quality of land, as shown in Scenarios 1-3, whichever educational level of household heads, the average probability for people being poor in the western regions was around 20 points higher than those in the central regions, and around 45 points higher than those in the eastern regions. The regional difference came to be smaller for the group of Han majority having higher quality of land (Scenarios 10 and 12). The effect of higher education levels on reducing the likelihood of being poor was much weak compared to India. Moreover, effects of education are more or less the same among three regions, between minority and majority, between those with more and those with less irrigated land.

Land status had greater impact on the likelihood of being poor for the western region and the central region than for the eastern region. For instance, for the western minority group, with a illiterate head the average probability of being poor was $53.7 \%$ if it had irrigated land less than dry land (Scenario 1) and $45.1 \%$ if it had irrigated land greater than dry land (Scenario 7); but for the eastern minority group with the same characteristics, the average probability was $7.3 \%$ and $5.0 \%$, respectively.

Was the difference in poverty incidence between minority people and majority people in the western region larger than that in the eastern region? The answer is 'Yes'. To make a comparison of Scenario 1 with Scenario 4, for those having illiterate heads and living with less share of irrigated land, it is apparent that the minority people had nearly 9 points higher poverty incidence than the majority people in the western region, while the difference is only 2 point for those in the eastern region. The same pattern can be found from other comparisons in terms of higher educational attainment and land irrigation. The comparison indicates again that rural poverty was more concentrated among the minority people in western China.

An overall conclusion from the results of the analysis presented in this section is that in China rural households with given characteristics face rather different probabilities of being poor due to region while this is much less the case for households living in India. People living in the western part of China face probabilities of being poor that are more similar to households living in India than households living in other regions of China. Further as in the income function analysis show education of household head as well as minority-majority status and access to land have larger effects on poverty status in India than in China.

\section{Conclusions}

In this paper, we compared, using microdata for both countries, income inequality and poverty in the rural parts of China and India. To the best of our knowledge, such analysis has not before been carried out for the two countries. We found that while average income in (rural) China was higher than in (rural) India, rural income inequality in the two countries was similar. 
Consequently, the fact a larger proportion of the Indian rural population was below the (common purchasing power) poverty line than in China was thus driven by differences in mean income between the countries.

The main conclusion of the paper is that although income inequality in rural China and rural India were similar, inequality and poverty were differently structured in the two countries. China displayed larger regional differences in mean income and poverty than India. Seen from the perspectives of the level of mean income, and from that of the risk of being poor for members of a household with given characteristics, the western part of China had more in common with the Indian regions than with the wealthy eastern part of China. For example, as much as about onefifth of income inequality in rural China would disappear if mean incomes in the three Chinese regions were the same, without any change in income inequality within the regions. Rural poverty in China is concentrated in its western region; on the other hand, the poor in India are more evenly spread across its regions.

While rural China is more unequal than India along the regional dimension, the opposite applies in the context of the educational level of household heads. A considerably smaller proportion of the Chinese respondents were illiterate compared to their Indian counterparts. Our results show a poorly educated household head was a much stronger predictor of low household income and high poverty in India than in China. While income inequality in India would reduce by almost $10 \%$ if - without any change in within-group inequality - the different educational groups had the same mean income, the corresponding reduction in China would be only $1 \%$.

India has a much larger proportion of its population belonging to the 'minority' group, as we have defined it. Therefore, the minority-majority dimension is more important in India than in China. Most of China's poor belong to the Han majority while most of India's poor are Muslims or belong to the Scheduled Castes/Tribes. Although our study found that the average minoritymajority income gap in China and India were similar in magnitude, the results from our multivariate analysis indicated that much of the minority-majority divide in China was due to the fact that China's minority population was located in its less developed western region. In India there was evidence of the unfavourable treatment of minority group persons living in the same location as persons from the majority group.

While Chinese rural households aiming to escape poverty had a strong incentive to emigrate from the western region (and even stronger incentives to migrate to urban areas), rural households in India had a strong incentive to invest in education. Our results also showed that, in both countries, households had incentives to improve their land status. That meant being a land owning household in India and having access to irrigated land in China.

\section{Acknowledgement}

We thank an anonymous referee for several useful suggestions which have greatly improved the paper.

\section{References}

Borooah, V. K. (2005). Caste, inequality and poverty in India. Review of Development Economics, 9, 399-414.

Cowell, F. A., \& Jenkins, S. P. (1995). How much inequality can we explain? A methodology and an application to the USA. Economic Journal, 105, 421-430.

Drèze, J., \& Sen, A. K. (1995). India: Economic development and social opportunity. New Delhi: Oxford University Press. Foster, J., Greer, J., \& Thorbecker, E. (1984). A class of decomposable poverty measures. Econometrica, 52, 761-766. 
Gustafsson, B., \& Li, S. (2001). A more unequal China? Aspects of inequality in the distribution of equivalent income. In C. Riskin, R. Zhao, \& S. Li (Eds.), China's retreat from equality: Income distribution and economic transition (pp. 44 83). Armonk, NY: M.E. Sharpe.

Gustafsson, B., \& Li, S. (2004). Expenditures on education and health care and poverty in rural China. China Economic Review, 15, 292-301.

Gustafsson, B., \& Wei, Z. (2000). How and why has poverty in China changed? A study based on microdata. China Quarterly, 164, 983-1006.

Gustafsson, B., \& Wei, Z. (2002). Determinants of rural poverty in China. China \& World Economy, 10(2), 41-49.

Khan, A. R., \& Riskin, C. (1998). Income inequality in China: Composition, distribution and growth of household income. China Quarterly, 164, 983-1006.

Khan, A., \& Riskin, C. (2001). Inequality and poverty in China in the age of globalization. Oxford: Oxford University Press.

Knight, J., \& Song, L. (1999). The rural-urban divide. Economic disparities and interactions in China. Oxford: Oxford University Press.

Riskin, C., \& Li, S. (2001). Chinese rural poverty inside and outside the poor regions. In C. Riskin, R. Zhao, \& S. Li (Eds.), China's retreat from equality: Income distribution and economic transition. Armonk, NY: M.E. Sharp.

Sen, A. (1976). Poverty: An ordian approach to measurement. Econometrica, 48, 219-231.

Shariff, A. (1999). India human development report. New Delhi: Oxford University Press.

Shorrocks, A. (1980). A class of additively decomposable inequality measures. Econometrica, 48, 613-625.

Smeeding, T. M., \& Weinberg, D. H. (2001). Toward a uniform definition of household income. Review of Income and Wealth, 47(1), 1-24 March.

Srinivasan, T. N. (2004). China and India: Economic performance, competition and cooperation. An update. Journal of Asian Economics, 15, 613-636.

Theil, H. (1967). Economics and information theory. Amsterdam: North Holland.

World Bank (2000). Attacking poverty. World development report 2000/2001. Washington, DC.

Zhang, X. B., \& Kanbur, R. (2001). What difference do polarisation measures make? An application to China. Journal of Development Studies, 37(3), 85-98.

Zhao, R., Li, S., \& Riskin, C. (Eds.). (1999). Zhongguo jumin shouru fenpei zai yangju [Re-study on income distribution of chinese households] Beijing: Publishing House of Chinese Finance and Economy. 